\title{
Cyclin-Dependent Kinase Inhibitor Gene
}

National Cancer Institute

\section{Source}

National Cancer Institute. Cyclin-Dependent Kinase Inhibitor Gene. NCI Thesaurus. Code C18593.

The CDK Inhibitor Genes encode the CDK Inhibitor Proteins, a group of low molecular weight proteins that associate with cyclin-CDK complexes or CDKs alone and inhibit their activity. (From OMIM and $\mathrm{NCl}$ ) 